\title{
MANIFESTATIONAL TOURISM IN THE FUNCTION OF THE CENTRAL SERBIA RURAL AREAS' DEVELOPMENT - AN EXAMPLE OF SUCH A MANIFESTATION "GUČA TRUMPET FESTIVAL"
}

\author{
Marina Ilinčić ${ }^{* 1}$ \\ "University of Belgrade - Faculty of Geography, Belgrade
}

\begin{abstract}
Touristically speaking, the rural areas of Serbia are not fully researched, hence there exist viewpoints that say that by the development of manifestational tourism the touristic potential of such areas can be raised to the higher level and be better presented to the foreign touristic market. The result of the previously stated would be the increase of the touristic demand-scale, and an effect on the decrease of negative demographic processes and preventing migration of young people from rural to urban areas, as well. Touristic Manifestation "Guča Trumpet Festival" with over 55 years of tradition presents one of the most prominent domestic brands recognizable in the world touristic market. Methodological contribution of the paper consists of displaying the terrainresearch results carried out in 2015 and an overview of the interdependence of the main motives that attract foreign visitors to this manifestation and the local-people's demographic characteristics, with an intention of pointing out the suggestion for improving the rural area developmental conditions. Data analysis was carried out in the package program for statistical analysis and the data processing (SPSS 20.00) and was based on the population registry, granted from National Statistical Service of Republic of Serbia. The gathered data have shown that the studied manifestation can play a role in the revitalization of the Dragačevo area, primarily because it is interesting to foreign visitors and generally foreign visitors are interested in longer stays if the more significant touristic offer is rendered, including the touristic values in the vicinal regions.
\end{abstract}

Key words: Manifestational tourism, rural areas, demographic processes, revitalization, Guča.

${ }^{1}$ Corresponding author: M. Ilinčić, University of Belgrade - Faculty of Geography, Studentski trg 3/III, 11,000 Belgrade, Serbia; e-mail: marinailincic@gmail.com 


\section{Introduction}

Forms of the tourism which superbly represent the significance of tradition for touristic-destination development are the rural and the manifestational ones. Music, entertainment, clothes, local gastronomic specialties, cultural characteristics, uniqueness of natural beauties, even the population's mentality and hospitality of the hosts themselves in the rural areas, present some of the factors which affect the tourists' awareness during the selection of the specific destination.

Xue, Kerstetter, Hunt, (2017), suggest that material benefits which stem from the touristic development in rural areas may have effect on the change of the rural-population identity. Szmigin et al, (2017) point out that during the last few years, music festivals evolved in such a manner that they became popular touristic destinations. They overtook the significant position in the world touristic-market which grew larger both in the matter of size and number, and it became dominant in the perception of specific market segments.

The motives for creating various manifestations may represent powerful factor in attracting foreign tourists to our country; by the attractiveness of the content they possess and the uniqueness of destinations in which they are held. Precisely speaking, the rural areas represent the special places; as regions of outmost values, as ecological oases, fortresses of traditional culture and diversity of ethno-cultural legacy, whereas the tourism presents one of the activities that can have significant influence on the economic, social, functional and physiognomic structure of rural areas (S. Pavlović, 2016). Throughout the world, since the beginning of the eighties in the 20th century, the manifestational tourism is mentioned as a distinctive industry of events, whereas in Serbia, not before the beginning of the 21st century, did it gain the significance as a prosperous form of tourism.

"Dragačevo trumpet festival in Guča" is a unique competition of the trumpet orchestras and one of the most important events of the overall folklore creativity and cultural amateurism in Serbia. First of all, it is a traditional music manifestation dedicated to competing of brass bands from all parts of Serbia and abroad, but it is also characterized by its accentuation on the ethnographic elements connected to the accompanying exhibitions of the folklore handicrafts, traditional cuisine and the works of self-taught painters, sculptors and poets, as well as competitions of traditional sport skills of this part of Serbia (Blešić et al., 2013). In other words, the purpose and objective of this manifestation are preserving and cherishing the authentic and traditional creativity and music; the central part of the manifestation is a contest of the trumpet 
Manifestational Tourism in the Function of the Central Serbia Rural Areas' Development An Example of Such a Manifestation "Guča Trumpet Festival"

orchestras. The festival usually lasts for five days, with an exception in 2015, when, in the honor of the 55th Trumpet Festival, it lasted for seven days.

Contemporary approach to this matter indicates that the rural areas are facing the need for utilizing new possibilities, which require high level of responsibilities and determination in finding the most appropriate solutions, as well as a certain degree of creativity and new attitudes toward resources. The necessity to diversify the rural economy in socially, economically and ecologically sustainable manner, ensued from the clear objectives, and these are improving the quality of life, reduction of poverty level, as well as struggle against the social and ecological degradation and preserving the living environment. In a response to the aforementioned issues, the tourism was identified to be a key domain that can initiate such a process.

The interest for rural areas has a long tradition, but the problem which is raised in nowadays geographic and tourismological studies defines rural areas in two categories: one that rural areas with its resources meats recreational needs and the other, that it meets the touristic ones. Traffic initiated by manifestational motives, can be viewed as touristic needs of rural areas. The term "Rural Area", the world perceives differently than we do, in the context of its size, its function in the space, population number, number of housing units and other characteristics. Such a notional distinction should be a stemming point for creation and development of touristic activities in specific environments. Furthermore, even the definition of rural areas does not exist in our statistics, which the world's praxis recognizes, as such. Criteria applied by the National Statistical Service of the Republic of Serbia do not include standard indicators of rurality which are used in international praxis (population number, participation of agricultural population) but consider to be rural those settlements which are not urban. Based on such interpretations, about $70 \%$ of Serbia (not including Kosovo and Metohija) represent rural areas in which $40 \%$ of the country's population lives. According to the latest population-registration from 2011, rural area of the Central Serbia takes up 83 municipalities, while there are 26 urban ones (М. Павловић, Шабић, Вујадиновић, 2015). The basic characteristics of Central Serbia rural-area economical structure, in the beginning of the 21st century, are presented by: traditionally high share of agricultural production and low share of Service Sector in the gross social product (Голић, Јоксимовић, Крстић, 2015) which are considered to be limiting factors for development.

For the first time in The Tourism Developmental Strategy of the Republic of Serbia from 2006 till 2015, manifestational tourism is indicated as a very significant segment in the foreigner-tourism development in Serbia, but 
also as a comparative advantage of the domestic tourism. The new "Tourism Developmental Strategy of the Republic of Serbia from 2016 till 2025" (2016), also points out the significance and the role of manifestational tourism as well as inciting rural and regional development and reduction of depopulation, as well as generating and maintaining positive image of Serbia throughout the world. According to the new strategy even the manifestations and the rural tourism are determined to be categories of priority activities which have to be developed continuously.

The research tasks are formulated in accordance with previous statements which give answers to the following questions: How can Manifestational tourism affect rural development and can a music event of the international character play a significant role in its socio-economic development? What can a rural area offer to foreign tourists regarding manifestations, i.e. which are the most significant pull factors to foreign tourists? According to answers to these questions it is possible to identify some of the key factors to success in development of this type of tourism in the rural area of Central Serbia and point out the possibilities of their complementary development.

\section{Methodological approach}

Research of the motives for touristic traffic is very significant because it represents an important indicator of some of the manifestation's successes and what are the reasons which motivate the tourists to visit Serbia. Thus, it is suggested to the organizers to modify the touristic offer according to the needs and requirements of demands. The study of the touristic manifestations for the need of valorization in tourism, include socio-psychological motives as push factors (non-material, inner wishes of the visitors) and the peculiarities of the destinations (natural and cultural resources, material base) where the manifestations are held, as pull factors (Илинчић, 2015).

The research methods entail terrain and cabinet surveys. The terrain survey is carried out by a random sample enquiries of the foreign visitors, in the place where the manifestation is being held - in Guča (3rd to 9th of August, 2015) and entails 204 respondents. The enquiry form in English consists of two parts: the first with socio-demographic characteristics of the respondents and the second, in the form of Lickhert's Scale of 31 motivators, where the respondents were asked to evaluate the importance of the given motivators (1-5). The data processing was being done by a program package for statistical processing and data analysis IBM SPSS Statistics 20. 
Manifestational Tourism in the Function of the Central Serbia Rural Areas' Development An Example of Such a Manifestation "Guča Trumpet Festival"

The methods of descriptive statistics were being used to describe the observed phenomena, whereas the parametric statistics methods (t-test) were being used for establishing possible differences among the respondents.

The obtained results were relevant for comprehending the main (i.e. the strongest and the weakest) motivators for foreign tourists visiting the manifestation "Guča Trumpet Festival" (Table 2).

\section{Results and discussion}

The world experience indicate a stance that as a result of business decline in traditional industries including agriculture, mining and forestry, the tourism is more growingly considered to be a potential and perspective economy branch, which gives more possibilities for employment of local population and additional income in rural communities. In other words, the tourism has become a developmental tool for many rural areas as an addition to the traditional industry. Migrations from rural to urban areas are still popular in Serbia, which by a one-way-road create slow-down in the development of rural areas, and they affect the employment rate, new possibilities for the young, maintaining the traditional handicrafts, cherishing the specific customs and the culture.

Table 1 - Comparative overview of the inhabitant and the household numbers in Guča

\begin{tabular}{|c|c|c|c|c|c|c|c|c|c|}
\hline \multicolumn{2}{|c|}{ Registration years } & 1948 & 1953 & 1961 & 1971 & 1981 & 1991 & 2002 & 2011 \\
\hline \multirow{2}{*}{$\begin{array}{l}\text { Guča } \\
\text { (Town) }\end{array}$} & $\begin{array}{l}\text { Number of } \\
\text { inhabitants }\end{array}$ & 601 & 754 & 932 & 1,378 & 1,852 & 2,026 & 2,022 & 1,755 \\
\hline & $\begin{array}{l}\text { Number of } \\
\text { households }\end{array}$ & 221 & 259 & 332 & 467 & 584 & 635 & 663 & 602 \\
\hline \multirow{2}{*}{$\begin{array}{c}\text { Guča } \\
\text { (Village) }\end{array}$} & $\begin{array}{l}\text { Number of } \\
\text { Inhabitants }\end{array}$ & 2,032 & 2,060 & 1,900 & 1,800 & 1,907 & 1,951 & 2,010 & 1,955 \\
\hline & $\begin{array}{l}\text { Number of } \\
\text { Households }\end{array}$ & 344 & 372 & 434 & 445 & 550 & 562 & 610 & 618 \\
\hline
\end{tabular}

Source: Републички завод за статистику, 2014 
The table 1 shows decrease in the number of inhabitants in Guča (town) from 1991 onwards, whereas the decrease in the (village) of Guča has been a characteristic since 2002. When the question of the number of households in the village of Guča is concerned, it can be stated that there was a noticeable decrease between the two registration periods, whereas Guča (town) shows considerable increase for 8 households in 2011 regarding the period from the year of 2002. This could be an indicator of a certain positive tendency, which fits into the viewpoint (М. Павловић, Шабић, Вујадиновић, 2015:24) that " the rural areas in developed European countries increasingly become adequate places for the quality life of their inhabitants". Positive tendencies are also reflected in the fact that the Moravica region is in the first place, i.e. at the position with the lowest recorded decrease among the areas of Central Serbia, in view of the decreasing trend of active-persons' participation (in overall population) - from only 54,6\% in 1981 to 43,1\% in 2011 (Живковић, Ђорђевић, Илинчић, Петровић, 2015). Demographic characteristics of rural settlements which have the households engaged in tourism can be significant indicators of the prognosis of future state of tourism (С. Павловић, Ђорђевић, 2013). Kоščak, points out that the key to success lies in the people who live, work and have rural roots, and whose descendants will stay in these areas:... "If you want a year of prosperity, you need to cherish the grain, if you want ten years of prosperity, you need to cherish the trees, but if you want a hundred years of prosperity, you need to cherish the people!" (Koscak, 1998:85).

According to contemporary considerations, the analysis and the prediction of demand for the specific events or events in certain areas (that include rural areas, as well) partly depend on the distribution (the number of inhabitants), as well as, on the possible interventions and competition on the market (Getz, Page, 2016).

Development of rural areas by expanding manifestational tourism, besides economic, includes both social and political significance, because the presence of foreign tourists apart from the realized "invisible export" through the foreign currency influx, also contributes to the better comprehension of the culture, the way of life, better comprehension of different nations, visitors of the manifestation from the different countries, but also getting to know the local population, thus pointing out the phenomenon of "socialization" as a one of the more prominent motivators when choosing the manifestation that the visitor wishes to see. The results of the research concerning the 55th Guča trumpet festival, indicate that, apart from the Trumpet - the music genre recognizable in almost all the places of the world, in addition to having good time, it is the socialization with other visitors and local population which presents one of the more prominent motivators, i.e. the initiator of the journey towards this part of Serbia. 
Manifestational Tourism in the Function of the Central Serbia Rural Areas' Development An Example of Such a Manifestation "Guča Trumpet Festival"

Table 2 - Descriptive statistics, differentiated motivators

\begin{tabular}{|c|c|c|c|c|c|}
\hline & $\begin{array}{c}\text { Total } \\
\text { Number of } \\
\text { Respondents } \\
\text { (N) }\end{array}$ & $\begin{array}{c}\text { Minimum } \\
\text { (Min.) }\end{array}$ & $\begin{array}{c}\text { Maximum } \\
\text { (Max.) }\end{array}$ & $\begin{array}{c}\text { Mean } \\
\text { value } \\
\text { (M) }\end{array}$ & $\begin{array}{c}\text { Standard } \\
\text { deviation } \\
\text { (df) }\end{array}$ \\
\hline Entertainment & 204 & 2 & 5 & 4.65 & 0.689 \\
\hline Socialization & 204 & 1 & 5 & 4.33 & 0.874 \\
\hline New experiences & 204 & 1 & 5 & 4.19 & 0.954 \\
\hline New cultures & 204 & 1 & 5 & 4.18 & 1.006 \\
\hline $\begin{array}{c}\text { Quality of } \\
\text { performers }\end{array}$ & 204 & 1 & 5 & 4.16 & 0.995 \\
\hline $\begin{array}{c}\text { Social significance } \\
\text { of the Festival }\end{array}$ & 204 & 1 & 5 & 3.18 & 1.236 \\
\hline $\begin{array}{c}\text { Information } \\
\text { rendered by } \\
\text { organizers }\end{array}$ & 204 & 1 & 5 & 3.17 & 1.236 \\
\hline $\begin{array}{c}\text { Popularity of } \\
\text { performers }\end{array}$ & 204 & 1 & 5 & 3.15 & 1.358 \\
\hline $\begin{array}{c}\text { Quality of the } \\
\text { Camp }\end{array}$ & 204 & 1 & 5 & 3.08 & 1.513 \\
\hline \begin{tabular}{c} 
Distance \\
\hline
\end{tabular} & 204 & 1 & 5 & 2.23 & 1.248 \\
\hline
\end{tabular}

Source: Author, based on the data from SPSS, 2015

The obvious indifference of the respondents towards the distance of the destination where the manifestation is being held, in regard to the country where they come from (Mean 2.23), can be interpreted by the fact that the respondents' priorities were good entertainment, music and socialization at the Festival, independent of the social significance of the Festival, even regardless of the popularity of the performers. Accordingly, overcoming the space as a barrier in regard to "staying a loyal tourist to this traditional manifestation, or getting there for the first time to experience it, was not a problem to them. Good entertainment, socialization, new experiences, new cultures and the quality of music performers were pointed out as the strongest motives for visiting Guča $(M>4)$.

In order to pin down whether the foreign visitors were interested in natural and cultural touristic values in the surrounding area, a question was raised:" Do you, throughout and after the Manifestation, visit touristic sights of the place where it is held and the sights of its surroundings"? 80, out of 204 respondents 
total, answered that they did, 61 respondents answered that they did but not every time (the more than five-time-visitors) while less than a third of the respondents gave negative answer. The Table 3. shows the countries from which the most interested visitors come to see natural and cultural values in the surrounding region. Therefore, the highest number of visitors from the particular country have not been taken into consideration in the survey, but those with the highest average values $(M>3)$. The gathered data are also valuable for the organizers of the manifestation throughout the sorting out specific segments of the demand and directing the adequate touristic offer toward them.

Table 3 -Visitors according to their interest in additional touristic values

\begin{tabular}{|c|c|c|c|}
\hline Country & $\begin{array}{c}\text { Number of } \\
\text { respondents } \\
\text { (N) }\end{array}$ & $\begin{array}{c}\text { Cultural and } \\
\text { historic values } \\
\text { (Mean) }\end{array}$ & $\begin{array}{c}\text { Natural values } \\
\text { (Mean) }\end{array}$ \\
\hline Italy & 22 & 3.64 & 3.09 \\
\hline Slovenia & 18 & 3.39 & 2.89 \\
\hline Bosnia and Herzegovina & 18 & 3.78 & 3.50 \\
\hline Russia & 7 & 4.00 & 4.29 \\
\hline Spain & 4 & 4.50 & 4.50 \\
\hline Switzerland & 4 & 4.00 & 5.00 \\
\hline
\end{tabular}

Source: Author, based on the data analysis of SPSS, 2015

It can be concluded, based on the represented data, that the mean values differ depending even on the number of visitors who participated in the enquiry, and who are, by itself, the representatives of their countries. Although such cases tend to be harder, meaning less plausible to make a generalization, nevertheless, it can be interpreted that the tendency to natural, cultural and historic values in the area-vicinity is not specific to every visitor from the country they come from. Some of the visitors were present at the festival only because of the festival itself and nothing else; they are also bound to stay only while the Manifestation lasts, and they do not have an ambition to prolong and enrich their stay by additional touristic content, while others are interested in the more content-rich touristic stay. These observations explain the bigger mean values where the number of respondents is less, and vice versa.

In order to establish the fact whether there is statistically significant difference among men and women regarding the attitude to visiting touristic values in the Guča vicinity, a T- test of independent samples was carried 
Manifestational Tourism in the Function of the Central Serbia Rural Areas' Development An Example of Such a Manifestation "Guča Trumpet Festival"

out. The results $(p=0,227 ; t=1,212 ; d f=202)$ indicate that there are no statistically significant differences between the two groups, because the significance level $(\mathrm{p}<0,05)$ is not observed.

Similar survey on motivators of the visitors was carried out by Blešić et al, (2013) at the jubilee of 55th Guča trumpet festival (2010). There were differentiated different dimensions of motivation to some extent in regard to this survey and these are: the program of the festival and the atmosphere, perception and learning about the festival, psychophysiological wellbeing and socialization.

In the rural areas of Serbia the development of tourism is specifically relevant if the challenges of the unemployment, depopulation and the need for diversification of the agricultural economy are taken into consideration. Namely, the manifestational tourism can provide additional income to the rural-area-population by the placement of the agricultural products, domestic creative works and handicrafts, not only on the streets (during the manifestation) but very often even in the someone's own backyard, which does not call for too much of additional costs to the local population, but simply, creates pure profit. Therefore, a multiplying effect is reflected in the fact that the rural areas where the tourism is developed would initiate even the greater agricultural development which would primarily affect the economic and social wellbeing of the population, and increase of the national product and the national income, as well. The agriculture and the tourism provide socioeconomic growth of the rural areas and the total development of their potential, hence they are regarded as a national platform for economic diversification in the rural areas (UNWTO, 2015). Njegovan, Demirović, Radović (2015) have recognized the fact that the rural development of Vojvodina, by the help of tourism (ethno and ecotourism, messuages and different events), can represent factors of revitalization of the countryside with the purpose of solving economic and demographic problems. Antić, Vujko, Gajić (2015) point out that the tradition is an initiator of the tourism development in the rural areas and it has positive effects on tourism, economy within the frame of cultural identity of rural areas in the municipality of Požarevac.

The tourism is an economic sector which can offer significant contribution to economic growth of the region, to secure the labor market and bring to the employment, through products and the necessary services for maintaining the touristic activities (Blešić et al, 2014). The rural area of Dragačevo provides valorization of the women's labor in the countryside households and employing the labor inactive categories of the population, which will present 
adequate means of gaining material benefits, whereas the Guča Manifestation itself presents adequate means of placement of such products. Throughout the years, the manifestation attracted more and more people, not only domestic, but the foreign visitors as well, which is of greatest significance not only for the economic income of our country, but for the development of the area where the event is held, as well. Complementarity of the various forms of tourism in the rural areas, such as ethno and ecotourism, contribute to the more complex comprehension of the area itself, necessary when its rehabilitation is concerned, whereas the mere tradition and cultural activities create a strong sense of belonging and identity of the local population (С. Павловић, 2015).

Local, regional, national and the international touristic values together with the attitudes of the tourists and the local population, have their own place in the touristic market and, each in its own way, affect the accomplishing the social and economic effects of receptive tourism (Stankovic, 2016). Nevertheless, Panyik, Costa, Ratz (2011) consider that more attention should be paid to the event-promotion on the local level through the local media and the local, touristic organizations with the active participation of touristic agencies, in order to reach a specific segment of the visitors more efficiently. The previous mentioned should be significant anyways, because the results of the enquiry have shown that the information from the organizers of the Manifestation are not of greater significance to the foreign visitors, and by this fact they might have thought on their lack or inadequacy of the mentioned information. Especially, this should be held in mind if more new visitors should be attracted to the Manifestation.

Culturally speaking, the manifestational tourism is considered to be an element of enriching the population, because of meeting the different cultures. Prognoses of the UNWTO say that by the year of 2020 the cultural tourism-market will have become one of the main forms of tourism, whereas numerous studies carried out in the beginning of the 21st century showed that these allegations had been correct and that the number of touristic visits to cultural objects and the Manifestations will undoubtedly have become greater (UNWTO, 2015; Ilinčić, Jovičić, 2015). The touristic demand for the specific (non-classical forms) of the touristic product possesses clear characteristics through the expressed wish of a tourist for the authenticity, the articulate demand of the tourist for experiencing local surroundings and the articulate demand of the tourist to be respected by the host (Pivac et al., 2011), which fits perfectly in the concept of this study. The aforementioned characteristics and the wishes of the touristic demand can be precisely meat in rural areas by organizing different events, i.e. by developing the manifes- 
Manifestational Tourism in the Function of the Central Serbia Rural Areas' Development An Example of Such a Manifestation "Guča Trumpet Festival"

tational tourism. On one hand, it is about the form of traffic which can be independently placed on the market, but on the other hand, it can be a significant complement to the other forms of tourist traffic (the congressional, sports, cultural, urban, rural and the transit tourism) thus enriching the total touristic offer. Globalization in the travelling and business, development of information and communication technologies, the increase in the personal incomes in the favor of the touristic travelling brought about the intensification of the competition among the touristic destinations. In such conditions, touristic fields that are questioned, are the ways by which the destinations and the local population should utilize new and adequate ways to create new and unforgettable experiences, as well as preserving the identity of the area (Mariani et al., 2014). Dalonso et al., (2014) suggest the so-called “Intertwining model" that implies studies on the impact of events in the establishing public policies of destinations in which the manifestations are held, from the tourist's perspective. This model analyses the relationships between the significance of meeting the tourist's wishes while experiencing the destination (touristic experience) and the capability of organizing and maintaining the implementation of the touristic potential (public policies). It is clear that each touristic activity creates experience, whether it is good or bad. Therefore, the main task of the touristic planners is to provide a tourist with an unforgettable and unexpected journey, in all possible ways. Mariani, Georgio (2017) contributed to the planning and conducting the event tourism, among the rest, primarily by introducing a completely new notion "the meta event". According to these authors the newly forged term denotes a "tool of the brand architecture" for rebranding and positioning wider touristic zones. The experience of the festival destination in itself presents the very thing which largely produces positive result while changing the impression on the destination which the tourist had before and after the journey (MartinSantana, Beerli-Palacio and Nazzareno, 2017). Matheson, Rimmer and Tinsley (2014) agree that the festivals and the manifestations can improve the impression on specific destination through a variety of foundational bases of the given location-attractions and thus promote and stimulate the development of tourism. The loyalty of the visitor to an event should be one of the most significant objectives for the organizers because it is the key component to the long lasting sustainability of the mentioned destination (Novello, Murias, Fernandes, 2016). The organizers of the event should suggest activities and attractions that would help visitors experience authenticity, because the perception of genuine experience can be observed as an additional initiation of pleasure. Connel, Page and Mayer (2015), through the research on seasonality of an event suggested connecting various activities as a good strategy 
i.e. an approach which offers more possibilities for business throughout the whole year. Destinations on the basis of specific event-tourism-strategy can point out the advantages, correct disadvantages or find possibilities for realizations of the set objectives and minimize threats. It is only significant that the event tourism strategy should be integrated within an overall destination tourism strategy or strategy on the national level (Getz, Page, 2016).

\section{Conclusion}

As there are no universal area-development programs (considering different natural, economic, socio-cultural, demographic and other characteristics of each individual area) there stems a need for an adequate regionalization which lies in complementary advantages by which certain regions are characterized and on the analyses of the indicators of demographic and economic development and quality of the area. The Manifestation that has more motives which can be accomplished, as it is in the case of Guča trumpet festival, where, through the natural, landscape, cultural and artistic motives can be created synthesis of the touristic offer, presented touristic values, which by the good organization can be utilized from the touristic, economic and socio-cultural aspect. Each place tends to create specific cultural characteristic or recognition. The benefits are multiple: for the local community, its population and on the national level. Searching for the new ways of ruralarea revitalization created the concept of primarily integral, rural development through the preserving rural landscape, protection and improvement of the living environment and reaffirmation of traditional cultural values of the rural area. The author suggests: cherishing and preserving traditional, touristic Manifestation in Guča, by enriching its contents to their visitors and its capability to motivate them by other values of its environment and attract or hold visitors even in the period when the Manifestation itself is not held.

Considering the possibilities of applying the concepts of the metaevents and portfolio-events give new possibilities for overcoming seasonal effect at the observed Manifestation; some future researches can be based on these applications.

\section{Acknowledgements}

The paper is the result of the research within the project no. 176008 funded by the Ministry of Education and Science of the Republic of Serbia. 
Manifestational Tourism in the Function of the Central Serbia Rural Areas' Development An Example of Such a Manifestation "Guča Trumpet Festival"

\section{References}

Antić, A., Vujko, A., i Gajić, T. (2015). Tradicija kao pokretač razvoja turizma ruralnih destinacija. Skola biznisa, Broj 2, 9-20.

Blešić, I., Pivac, T., Đorđević, J., Stamenković, I. and Janićević, S. (2014). Cultural events as part of cultural tourism development. Case study: Sombor and Apatina (Serbia). Acta geographica Slovenica, 54-2, 381-390.

Blešić, I., Pivac, T., Stamenković, I. and Besermenji S. (2013). Motives of visit ethno music festivals with regard to gender and age structure of visitors. Event Management, 17(2), 145-154.

Connell, J., Page, S. J., and Meyer, D. (2015). Visitor attractions and events: responding to seasonality. Tourism Management, 46, 283-298.

Dalonso, S. Y., Lourenco, M., J., Remoaldo, C. P. and Netto Panosso, A. (2014). Tourism experience, events and public policies. Annals of Tourism Research (46), 163-184.

Getz, D., Page, J. S. (2016). Progress and prospects for event tourism research. Tourism Management, 52, 593-631.

Ilincic, M., Jovicic, D. (2015). Perspectives of cultural tourism in the modern tourism market. Bulletin of the Serbian Geographical Society, Tome XCV, No 1, 31-41.

Koscak, M. (1998). Integral development of rural areas, tourism and village renovation, Trebnje, Slovenia, Tourism Management Vol.19, No1,81-86.

Mariani, M. M., Buhalis, D., Longhi, C., and Vitouladiti, O. (2014). Managing change in tourism destinations: Key issues and current trends. Journal of DestinationMarketing \& Management, 2(4), 269-272.

Mariani, M. M., Giorgio, L. (2017). The "Pink Night" festival revisited: Metaevents and the role of destination partnerships in staging event tourism, Annals of Tourism Research (62), 89-10.

Martín-Santana, D. J., Beerli-Palacio, A. and Nazzareno, A.P., (2017). Antecedents and consequences of destination image gap. Annals of Tourism Research (62), 13-25.

Matheson, C. M., Rimmer, R.and Tinsley, R. (2014). Spiritual attitudes and visitor motivations at the Beltane Fire Festival, Edinburgh, Tourism Management $44,16-33$. 
Njegovan, Z., Demirović, D. i Radović, G. (2015). Upravljanje održivim razvojem ruralnog turizma u Vojvodini, Škola biznisa (1), 68-79.

Novello, S., Murias Fernandes, P. (2016). The Influence of Event Authenticity and Quality Attributes on Behavioral Intentions. Journal of Hospitality $\mathcal{E}$ Tourism Research, Vol. 40, No. 6, 685-714.

Panyik, E., Costa, C.and Ratz, T. (2011). Implementing integrated rural tourism: An event-based approach, Tourism Management (32), 1352-1363.

Pavlović, S. (2016). Elements of Tourist Destinations - Example of Touristrecreation Centre in Koštunići. Collection of Papers - Faculty of Geography at the University of Belgrade, 64, 469-480.

Pivac, T., Blešić, I., Stamenković, I., Besermenji, S. (2011). Event management and consumer satisfaction in tourism industry. African Journal of Business Management, Vol. 5(34), pp.13240-13248, DOI: 10.5897/AJBM11.1641.

Stanković, S. (2016). Theoretical Foundations of Tourist Valorisation. Collection of Papers - Faculty of Geography at the University of Belgrade, 64, 27-46.

Szmigin, I., Bengry-Howell, A., Morey, Y., Griffin, Ch. and Riley, S. (2017). Socio-spatial authenticity at co-created music festivals. Annals of Tourism Research, (63), 1-11.

Tourism Development Strategy of the Republic of Serbia 2016 - 2025. (2016). Belgrade: Goverment of the Republic of Serbia, Ministry of Trade, Tourism and Telecommunications.

World Tourism Organizacion (2015). UNWTO Tourism Highlights 2015 Edition.

Xue, L., Kerstetter, D. and Hunt, C., (2017). Tourism development and changing rural identity in China. Annals of Tourism Research (66), 170-182.

Голић, Р., Јоксимовић, М. и Крстић, Ф. (2015). Циљеви, услови и смернице развоја руралног простора Централне Србије. У Павловић, М., Шабић, Д. и Вујадиновић, С. (ур.): Развојни потенцијали и оганичења ревитализације руралног простора Центтралне Србије, (стр. 51-69). Београд: Универзитет у Београду - Географски факултет.

Живковић, Д., Ђорђевић, Т., Илинчић, М. и Петровић, љ. (2015). Економска структура становништва. У Павловић, М., Шабић, Д. и Вујадиновић, С. (ур.): Развојни потенцијали и оганичења ревитализације руралног простора Централне Србије, (стр. 197-226). Београд: Универзитет у Београду - Географски факултет. 
Manifestational Tourism in the Function of the Central Serbia Rural Areas' Development An Example of Such a Manifestation "Guča Trumpet Festival"

Илинчић, М. (2015). Географски аспект проучавања и анализа главних обележја три најзначајније туристичке манифестације у Србији (Гуча, Exit и Beer Fest). У Зборник радова младих истраживача:,,Достигнућа, актуелности и изазови географске науке и праксе", (стр. 145-150). Београд: Универзитет у Београду - Географски факултет, Српско географско друштво.

Павловић, М., Шабић, Д. и Вујадиновић, С. (2015). Теоријске основе истраживања руралног простора. У Павловић, М., Шабић, Д. и Вујадиновић, С. (ур.): Развојни потенцијали и оганичења ревитализације руралног простора Централне Србије, (стр. 11-27). Београд: Универзитет у Београду - Географски факултет.

Павловић, С. (2015). Трговина и туризам. У Павловић, М., Шабић, Д. и Вујадиновић, С. (ур.): Развојни потенцијали и оганичеть ревитализације руралног простора Централне Србије, (стр. 281-297). Београд: Универзитет у Београду - Географски факултет.

Павловић, С. и Ђорђевић, Т. (2013) Прогнозе развоја сеоског туризма у општинама Косјерић и Горњи Милановац, Зборник радова, 63(1), Географски институт „Јован Цвијић“, 47-65.

Републички завод за статистику. (2014). Попис становништва, домаћинстава и станова 2011. године у Републици Србији,Књига 20, Упоредни преглед броја становника 1948, 1953, 1961, 1971, 1981, 1991, 2002 и 2011, подаци по насељима, Београд: Републички завод за статистику.

Републички завод за статистику. (2014). Попис становништва, домаћинстава и станова 2011. године у Републици Србији,Књига 21, Упоредни преглед броја домаћинстава 1948-2011 и станова 1971-2011, подации по насељима, Београд: Републички завод за статистику. 